\title{
Die Dordtse Kerkorde van 1619 en die NG Kerkorde van 1962: Laasgenoemde ' $n$ ontwikkeling van eersgenoemde ten opsigte van die kerklike tug?
}

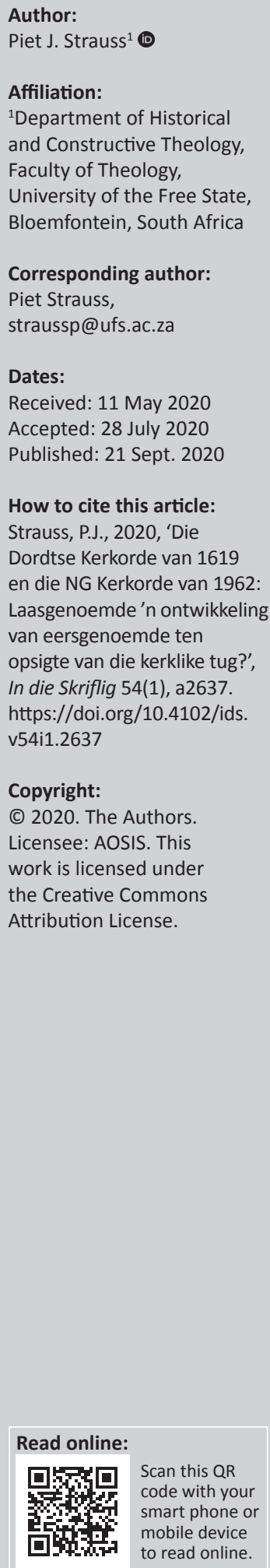

\begin{abstract}
The Church Order of Dordtrecht of 1619 and of the Dutch Reformed Church of 1962: The latter a developement of the former on church discipline? A spokesman for the Commission of Actuarii who drafted the Church Order of the Dutch Reformed Church for a newly founded general synod in 1962, J.D. Vorster, called it an example of the Church Order of Dordt of 1619 for present times. That meant that this Church Order used the same principles or constants as Dordt, but under different circumstances. The influence of the Church Order of Dordt on the Church Order of the Dutch Reformed Church of 1962 on church discipline is investigated. The latter indeed used constants of the former, but also revealed new developments: developments of a reformational nature and not only with regard to new circumstances, but also in the formulation and usage of some constants. What the Church Order of the Dutch Reformed Church also took over from the Church Order of Dordt, was a list of sins which made it difficult for ministers to be reinstalled after they have sinned.
\end{abstract}

Keywords: Church Order; Dutch Reformed Church; Church; ministers; Sin.

\section{Inleiding}

J.D. Vorster, die eerste aktuarius ${ }^{1}$ of persoon verantwoordelik vir kerkordelike sake op die eerste Algemene Sinode van die Nederduitse Gereformeerde Kerk (NGK), die sinode van 1962, noem NG Kerkorde-1962 (NGKO-1962) (vgl. NGK 1964) van hierdie sinode ‘Die Dordtse Kerkorde (DKO-1619) aangepas by die eise van ons dag' (Vorster 1960:13). Volgens bronne skryf Vorster die eerste vier van ses hoofstukke van die NGKO-1962 en redigeer die res (Langner 2007:87). Die feit dat hy deur die Algemene Sinode as aktuarius gekies word, onderstreep sy beeld as kundige oor kerkordelike sake in die NGK. Hierdie verkiesing bevestig ook sy gesag wanneer hy namens die Kommissievan Aktuarii praat. Laasgenoemdewas vir diekonsep van NGKO-1962 verantwoordelik (Van der Watt 1973:165).

Wat Vorster betref, oriënteer NGKO-1962 op DKO-1619, of is NGKO-1962 'n verlengstuk van DKO-1619. Met sy opmerking impliseer hy 'n bepalende kontinuiteit sowel as 'n sekere diskontinuïteit van DKO-1619 met NGKO-1962. Die kontinuïteit hang saam met konstantes ${ }^{2}$ in DKO-1619 wat bepalend inwerk op konstantes of beginsels in die bepalings van NGKO-1962, terwyl die diskontinuiteit die verskil in die konteks of omstandighede van die twee aandui. Vorster se stelling is 'n prinsipiële 'ja' dat NGKO-1962 as 'n eietydse weergawe van DKO-1619 moet aanpas by die eise van 1962: ' $n$ norm vir gereformeerde kerkordes as dokumente van relevante Woordgebonde kerke in hulle situasie (Strauss 2010:15 e.v.).

'n Tipiese gereformeerde vereiste vir NGKO-1962 in sy verhouding tot DKO-1619 waarop Vorster nié wys nie, hang saam met die vraag of NGKO-1962 in sy verwoording van die konstantes of beginsels van DKO-1619 van 'n ontwikkeling en verdieping van hierdie waarhede getuig. Die vraag is nie net of NGKO-1962 met sy orde op dieselfde beginselspore as DKO-1619 loop nie, maar of hy in sy formulering van hierdie beginsels uit 'n reformatoriese hoek blyke gee van ontwikkeling en verdieping. Het die gereformeerde kerkordelike vereistes vir kerklike tug sedert 1619 'n reformatoriese groei ondergaan? Beteken die reformatoriese stelreël ecclesia reformata semper reformanda ['n gereformeerde kerk reformeer steeds] (Koffeman 2009:35) dat NGKO-1962 ten opsigte van sy bepalings vir die kerklike tug - in beginsel en in sy situasiegerigte toepassing as 'n kant daarvan - vanuit DKO-1619 gereformeer of ontwikkel het?

1.Rossouw (1979:44) noem hierdie soort aktuarius'n kerkregkundige.

2.Vergelyk Koffeman (2009:104) se gebruik van die term bepalende constante as hy stel dat die kerk of gemeente draai om Woord en sakrament: 'Dat is de grote en alles bepalende constante in het leven van de kerk.' 
Dit is op dié ietwat ongewone vraag in gereformeerde kerkreg dat hierdie artikel ingaan.

NGKO-1962 se band met DKO-1619 loop, soos die Kerkorde van die Christian Reformed Church (CRCN) in North America (CRCNKO), deur die Kerkorde van die Gereformeerde Kerke in Nederland (GKN) van 1959 (GKNKO-1959). NGKO-1962 sowel as CRCNKO-1965 gebruik GKNKO-1959 as hulle voorbeeld om deur hierdie kerkorde hulle band met DKO1619 te behou. Die Kommissie van Aktuarii wat vir NGKO1962 sorg (NGK 1962:31), kry in 1957 by die Federale Raad van NG Kerke - die voorloper van die Algemene Sinode toestemming om nie ' $n$ nuwe kerkorde vir die komende algemene sinodale verband van die NGK op te stel nie, maar GKNKO-1959 te hersien (Engelhard \& Hofman 2001:14; NGK 1957:31). GKNKO-1959 is 'n kerkorde wat soos die Kommissie van Aktuarii met NGKO-1962, 'n weergawe van DKO-1619 by die eise van die dag aangepas wil wees (Langner 2007:87; NGK 1957:73-74). Gevolglik loop die hoofstukindeling van NGKO-1962 en GKNKO-1959 sowel as sekere formulerings in beide soos dié van DKO-1619. Daarby neem NGKO-1962 sekere formulerings van GKNKO-1959 as 'n verruiming en 'n verafrikaansing van DKO-1619 oor (Strauss 2010:8).

Die geldigheid van hierdie roete om na byna 350 jaar by DKO-1619 met ' $n$ gerigtheid op die eie situasie uit te kom, word deur Nauta se kommentaar op GKNKO-1959 versterk. In sy kommentaar op hierdie Kerkorde oor die kerklike tug praat hy van DKO-1619 as die 'oude' en GKNKO-1959 as die 'herziene kerkorde' (Nauta 1971:348, $352,354,355,365)$. Die mees waarskynlike betekenis van sy woorde is dat GKNKO-1959 die kerkordelike reëlings of toepassings van DKO-1619 vir 'n nuwe tydvak wou hersien, maar in die proses by die kern van die konstantes van DKO-1619 as die tekens waaraan sy (Nederlandse of Nederduitse) gereformeerdheid uitgeken word, wou bly en dat GKNKO-1959 niks meer as DKO-1619 in 'n nuwe tydvak met nuwe eise wou wees nie. Dit is 'n vertrekpunt wat deur Vorster en kie in die Kommissie van Aktuarii gedeel en in 'n nuwe NGKO-1962 verwoord is.

Die vraag is: Is NGKO-1962 met sy bepalings 'n ontwikkelde en verruimde weergawe van die konstantes van DKO-1619 in die situasie van die NGK in 1962?

\section{Tug in die hart van die kerklike bediening}

Teenoor Nauta se koppeling van GKNKO-1959 aan DKO1619 oor die kerklike tug, sou 'n volgende geslag, oudgereformeerd, maar nou in die Protestantse Kerk in Nederland, volg. Konstantes in GKNKO-1959 waaroor Nauta skryf en wat vroeër in DKO-1619 verwoord is, word deur hulle afgewys. Koffeman (2009:282) verwerp Dordt se standpunt dat die kerk die tug moet gebruik om die sondes te straf as ' $n$ 'inhoudloze kerkordelijke aangeleentheid'. Vir hom is die kerklike tug nie 'n hulpmiddel vir die kerk om sy roeping te vervul nie. Etiese beslissings oor reg en verkeerd - soos in die gay-kwessie - word volgens Koffeman deur die kultuursituasie bepaal. Sy maatstaf vir reg en verkeerd is nie bybelse norme nie, maar opvattings in die sogenaamde 'Christelike' Nederland. Vir hom is Woordgebonde tug onbestaanbaar. Christusregering in die kerklike tug deur Woord en Gees is vir Koffeman nie realisties nie.

Hierteenoor wys Visser in die Gereformeerde Kerke in Suid-Afrika (GKSA) daarop dat'n kerkraad wat nie tug toepas nie, liefdeloos optree. So 'n kerkraad laat sy afgedwaalde lidmaat voortgaan 'totdat hy oplaas die verderf instort' (Visser 1999:262). Bouwman (1985:601), Nauta (1971:16-18), Jonker (1965:12), Engelhard en Hofman (2001:441), asook DKO-1619 en NGKO-1962 staan prinsipieel op dieselfde lyn as Visser. Vir Bouwman verteenwoordig die kerklike tug die 'handhaving van de heerschappij van Gods Woord in de kerk'. As jy die Woord en sakramente soos uiteengesit in die Nederlandse Geloofsbelydenis (NGB) artikel 29 suiwer bedien, móét jy eventueel stuit op die kerklike tug (Bouwman 1985:601). Engelhard en Hofman beskou die kerklike tug as 'n saak wat in die hart van die bediening lê en in die liefde van die Here God gegrond is. Soos ander Engelssprekende gereformeerdes leer hulle: 'Discipline is at heart discipling ...' (Engelhard \& Hofman 2001:441; vgl. Gray \& Tucker 1999:163). Uit sy soteriologie, versterk Smit (2009) hierdie standpunt met sy 'compassionate justice'. God gee aan sondaars wat dit nie verdien nie, 'n verlossende geregtigheid om Christus ontwil. Smit (2009:377) beskou die Here se geregtigheid as 'n omgeegeregtigheid: 'n bewys van sy verbondstrou.

Die eiening van die kerklike tug as ' $n$ saak wat in die hart van die kerklike bediening lê, maak daarvan 'n onmisbare deel van 'n gereformeerde kerkorde. Die NGB bely en onderstreep dit as hy in artikel 29 na die merktekens van die ware kerk verwys: die notae ecclesiae. Vir die NGB is hierdie merktekens die suiwere bediening van die Woord, die sakramente en die kerklike tug. Daarom, kerk sowel as kerkorde draai rondom hierdie drie merktekens as die skarniere van die kerklike lewe en daarom ook sy orde (NG Kerk-Uitgewers 1982:29). ${ }^{3}$ Om Smit se toegekende geregtigheid hiermee te integreer: tug is deur Woord en sakrament-Skriftuurlik verstaan - onweerstaanbare liefdesen genademiddele om die sondaar in hart, siel en lewe vir God se saak te wen. Dit is 'n toegekende vryspraak wat die mens se deel word deur sy gelowige aanvaarding daarvan deur Woord en Gees - 'n vryspraak wat die uitverkorene vir ewig aankleef omdat dit God is wat werk, en omdat God kies, toeken, begenadig en bewaar.

Teen hierdie verduidelikende agtergrond vir die kerklike tug sowel as die besef dat kerklike tugsake deur amptelike kerkvergaderings hanteer word (vgl. die NGK se kerkvergaderings in NGKO-1962 artikel 18, naamlik kerkraad, ring, sinode en Algemene Sinode met laasgenoemde in hoofletters omdat dit 'n eienaam is [NGK 1964:5]), kom die insig dat die amptelike kerklike tug ook moet voldoen aan die algemene kerkordelike vereistes vir kerkvergaderings.

3.Celliers (2003:307-312) noem Skrif en belydenis die norma normans en norma normata van die kerk. Dit vorm die prinsipiële basis of geloofsidentiteit vir alle kerklike strukture insluitend die kerkorde. 


\section{Algemene vereistes vir kerkvergaderings en tug: Die kerk'n geloofs- en liefdesgemeenskap}

Die eerste eis wat genoem kan word, is dat kerkvergaderings as amptelike vergaderings van die ampte in die gemeente (die kerkraad) of van afgevaardigdes van gemeentes in meerdere vergaderings soos ringe of klasses (klassisse), ${ }^{4}$ sinodes of partikuliere of provinsiale sinodes en algemene of generale of nasionale sinodes nie tugsake moet hanteer wat nie kerkordelik daar hoort of buite ' $n$ vergadering opgelos kan word nie (NGK 1964:5). Kerkordes moet voorsien dat 'n saak deur gesprek of pastoraat nie-amptelik of in der minne buite 'n vergadering opgelos of geskik kan word (NGKO-1998:21). Die Woord van God en pastorale insig werk ook buite kerkvergaderings. Kerkvergaderings moet ook nie deur beuselagtighede opgehou word indien die betrokke saak op 'n ander manier opgelos kan word nie (Sadler 1979:58). 'n Kerklike aanvoeling wat maniere ontwikkel om minder ernstige kwessies sonder die hangende moontlikheid van 'n amptelike kerklike tugsaak te hanteer, is ' $n$ bewys van mondigheid en geloofsgroei by die gelowiges of kerkmense.

In hierdie opsig kan DKO-1619 en NGKO-1962 met mekaar vergelyk word. Hoewel DKO-1619 in sy bepalings oor die 'Christelijke straf' of 'kerkelijke censuren' op sy bondige manier - 'n gereformeerde kerkorde moenie die kerklike lewe oorreglementeer en die leiding van die Bybel deur mensgemaakte reëls verduister nie - konsentreer op tug deur vergaderings, wys hy ook op die voorskrifte van Matteus 18. Met ander woorde, hoewel DKO-1619 nie bepalings daaroor gee nie, wys hy op Matteus 18:15 se 'as jou broeder teen jou sondig' (Afrikaanse vertaling van 1933; vgl. Jonker 1959) en ignoreer hy nie die onderlinge opsig en tug tussen gelowiges nie (teks van DKO-1619 in Pont 1981:184-185).

NGKO-1962 volg GKNKO-1959 in hierdie kwessie. NGKO1962 maak 'n onderskeid tussen twee soorte sondes: geheime en openbare ergerlike sondes. Vir geheime sondes gee hy die prosedure van Matteus 18:15-16. Indien die beweerde oortreding(s) egter van 'n openbare, aanstootlike aard is of daartoe ontwikkel, word dit deur 'n klag of gerug by die betrokke kerkvergadering aanhangig gemaak. In NGKO1962 artikel 61(a) word lidmate ook daarop gewys - DKO1619 bevat nie hierdie reëling nie en NGKO-1962 neem dit woordeliks by GKNKO-1959 artikel 104.2 oor - dat hulle mekaar moet vermaan en sulke sake as ernstig moet beskou. Hierdie bepaling verteenwoordig ' $n$ verbreding van DKO1619. Later toon NGKO-1998 'n verdieping in versoening wanneer hy bepaal dat 'n kerkvergadering by die ontvangs van 'n klag, gerug of verslag van 'n beweerde tugwaardige sonde (laasgenoemde word 'n reëling in NGKO-1998:21), eers twee moontlikhede oorweeg: Eerstens, of die beweerde

\footnotetext{
4.Die NGK-term ring kom waarskynlik van die Hervormde Kerk in het koninkrijk der Nederlanden. In sy Algemene Reglement van 1816, word bepaal dat elke klassis verdeel word in ringe wat sorg vir die bediening in vakante gemeentes en die verdeel word in ringe wat sorg vir die bediening in vakante gemeentes en die onderlinge versterking en opskerping van die predikante in die ring. Die ring word
waarskynlik beperk tot die predikante van die gemeentes in die ring (Pont 1991:40).
}

oortreding van 'n tugwaardige aard en dus ontvanklik is; en tweedens, of die saak, 'waar toepaslik', nie eerder deur herderlike sorg, versoeningsaksies of die hantering daarvan as 'n geskil opgelos kan word nie (NGKO-1998:21). Vanuit DKO-1619 se tug wat die sondaar met die kerk en sy naaste wil versoen, groei daar uit NGKO-1998 dus nog 'n alternatiewe maar tipies kerklike metode om aan hierdie versoening te werk.

In die gees hiervan voer Sadler (1979) aan dat kerklike tug die 'grootste speelruimte' in sy toepassing vereis. Hier is nie plek vir mensgemaakte, onbuigbare, vaste voorskrifte of gedetailleerde reglemente nie. Hy glo dat die toepassing van die bybelse norme van liefde en geregtigheid in die omstandighede met die oog op tasbare berou by die sondaarvir sy behoud en vir goeie verhoudings in die kerk - die tug reg stuur. Kerklike liggame wat die tug hanteer, moet binne hierdie parameters 'n geloofsaanvoeling en -diskresie ontwikkel om van tug 'n pastorale, regverdige uitreik na die beweerdes of geïmpliseerdes te maak. 'n Kerkorde moenie ' $n$ wet word wat hierdie speelruimte bedreig en beperk nie 'n speelruimte wat "n hoë mate van soepelheid en aanpasbaarheid' verg, veral rondom die tyd en omstandighede waarin die tug toegepas word. Gereformeerde vaders soos die Dordts gereformeerdes wou nie die siel uit die tug verwyder deur die invoer van 'n 'boekdeel met reglemente' soos die Roomse Corpus Iuris Canonici nie (Sadler 1979:30-34). Gekoppel aan die moontlikheid dat tugsake voor kerkvergaderings buite hierdie vergaderings opgelos kan word, dui hierdie saak op 'n vereenvoudiging sowel as verruiming van Dordt se visie op die kerklike tug. Dit skep nog 'n moontlikheid vir die tug as 'n pastorale handeling.

Kundiges oor die kerklike tug wat NGKO-1962 artikel 57 in gedagte hou, voer aan dat die 'opsieners' in kerklike tugsake nie soos regters nie, maar as vaderlike opsieners 'met diepe ootmoed voor God en ... tere liefde en belangstelling' oortreders moet terugbring van hulle dwaalweë. So bly die kerk by kerklike sake op 'n kerklike wyse en grens hy hom af teenoor die meer saaklike, dwingende aard van 'n burgerlike hof as 'n staatsinstelling. ${ }^{5}$

Die tweede vereiste is dat kerkvergaderings hulle hou by DKO-1619 artikel 30 en NGKO-1962 artikel 21, naamlik dat hierdie vergaderings kerklike sake op 'n kerklike wyse hanteer selfs al gaan dit oor 'n tugsaak na aanleiding van gedrag buite die kerk. Kerkvergaderings moet glo dat die kerklike tug deur die kerk as 'n geloofs- en liefdesgemeenskap wat regverdig én oortuigend en nie wetsdwingend nie optree, beoefen word (NGKO-1962 artikel 57 in NGK 1964:5; DKO1619 artikel 71 in Pont 1981:179). Hierdie ingesteldheid moet in kerkvergaderings groei en bestendig word. Kerklike sake op 'n kerklike wyse deur kerkvergaderings vra 'n beheersing van die aard van kerkwees in hierdie vergaderings.

5.Die begrippe vaderlijke opzieners teenoor burgerlijke regtpleging en regters word ontleen aan die Algemene Reglement van 1816 artikel 6 van die Hervormde Kerk in Nederland. In die tugreglement van 1824 artikel 48 van die NGK aan die Kaap word verwys na tugsake wat as kerklike sake op kerklike wyse hanteer moet word. Sake warin kerkvergaderings hulle daarvan weerhou om die styl of wyse van "het waarin kerkvergaderings hulle daarvan weerhou om die styl of wyse van 'het
Burgerlijk bestuur of Regtspleging' te gebruik (Pont 1991:65, 224-225). Let op die kruipende verafrikaansing in 1824 in die spelling van 'regtspleging'. 
Later verruim en vergemaklik NGKO-1998 kerklike sake op 'n kerklike wyse met (alle) 'sake vanuit kerklike perspektief, in die lig van die Woord van God en op kerklike wyse' (NGKO-1998:9). Hierdie bewoording vat die saak uit 'n wysgerig ekklesiologiese hoek beter raak en maak die NGK vry om in die lewe waarin alles met alles saamhang, sy profetiese stem te laat hoor - 'n stem wat praat wanneer menslike optrede die Woord of die geloofsbelang van die kerk kruis;'n stem wat nie deur'n voorafbepaalde onderskeid tussen kerklike, gemengde nie-kerklike kategorieë van sake'n ou Dordts gereformeerde gebruik - stilgemaak word nie. Die kruising kom wanneer rugby 'n afgod word of 'n nuwe rassisme in Suid-Afrika regering in algemene regsbelang verhoed (Biesterveld \& Kuyper 1905:63, 102; Spoelstra 1989:181-182; Strauss 2010:59-61).

Hoewel kerklike tugvergaderings beslis oor wat die eise van die Woord vir die lewe moet wees, moet hulle optrede gemik wees op versoening en herstel voor die Here God. En omdat die verlossing van God die rower aan die kruis op Golgotha kon insluit, kan die mens met sy beperkte, sondige verstaan van dinge nie bepaal waar en wanneer aksies om vergifnis voor God stop nie. Die Here se vergifnis van 'n 70 keer 7 keer gee 'n nimmereindigende, maar menslik onverstaanbare karakter daaraan. DKO-1619 artikel 71 se doel van die kerklike tug, naamlik om die sondaar met die kerk en sy naaste te versoen en ergernis uit die gemeente te verwyder, kry in NGKO-1962 artikel 57 'n dieper dimensie met begrippe soos vaderlik, ootmoed voor God en 'tere' liefde téénoor die staatsregtelike benadering van 'het burgerlijk gericht of straf der overheid' (NGK 1964:12; Pont 1981:184). GKNKO-1959 artikel 106 stimuleer NGKO-1962 moontlik met sy bepaling dat die kerklike tug geestelik van aard is en 'wereldse machtsoefening' moet vermy. Hierdie stelling sluit indirek aan by DKO-1619 se implikasie dat die kerklike of Christelike tug 'benewens' of naas die burgerlike straf sy plek het (Nauta 1971:358; NGK 1964:12; Pont 1981:184).

\section{Algemene vereistes vir kerkvergaderings en tug: in diens van die Woord}

'n Derde eis waarna verwys moet word, is dat 'n kerkorde in diens van die Woord van God die goeie orde en welsyn van die kerk bevorder. ${ }^{6}$ In ooreenstemming met Bucer en Calvyn as die vaders van die gereformeerde kerkreg (Spoelstra 1989:16), is Nauta oortuig dat 'n kerkorde afgestem moet wees op die plek waar Woord en sakrament bedien en die tug beoefen word en 'dergelijke'. Hierdie bepalings moet weerspannigheid, verwarring, woelings en twiste in die kerk voorkom en betrek word by ritusse, seremonies, tug en vrede in diens van Woord en sakrament. Die kerkorde oor die kerklike tug moet die kerk help om sy roeping te vervul en, gehoorsaam aan God, alles tot sy eer te doen. Bouwman voer reeds in 1928, voor latere steun hiervoor, aan dat 'n goeie kerkorde die kerkpraktyk dien en op 'n dienende kerkreg berus. Dit gaan

6.Kleynhans wys daarop dat die tug as deel van die sleutelmag wat die hemele vir mense oop- en toesluit terwyl dit draai om die boodskap van die Skrif, aan die kerk gegee is (Matt 18:18; Kleynhans 1988:140-141). in 'n kerkorde om diens aan bybelse waarhede en 'n Woordgetroue kerk (Bouwman 1985:596; Koffeman 2009:90; Plomp 1992:38-40; Strauss 2009:494-495). Terme in NGKO1962 artikel 56 en 57 soos dat tug tot die eer van God en heil van die gemeente uitgeoefen moet word en deur vaderlike opsieners wat in ootmoed en liefde tugtig, vat hierdie waarheid van diens aan die Woord goed raak (NGK 1964:12).

Die vierde eis wat hier genoem moet word, is dat die deelnemers aan 'n kerklike tugsaak die basiese begrippe wat hier ter sprake is, moet ken en verstaan om misverstand, onrus en spanning te voorkom. Die groot probleem is waarskynlik dat lidmate die aard en doel van die kerklike tug misverstaan. Uit die Verenigde State wys die presbiteriane, Gray en Tucker, daarop dat 'discipline' en 'disciple' verwant is. Albei kom van die woord 'discere' of om te leer (Gray \& Tucker 1999:163). In sy kern gaan dit om mense as individue vanuit hulle harte aan bepalende geloofs- en lewensoortuigings te bind. Kerklike tug, soos die res van die werk van die kerk, trek en behou die individuele gelowige - al is hy of sy deel van 'n saak waarby meer mense betrek word - deur persoonlike oortuiging. ${ }^{7}$ Geloofswaarhede kan alleen uit die hart bely word as dit 'n diep innerlike oortuiging en daarom ' $n$ vaste wete en vertroue is. ${ }^{8}$ Nauta (1971:358) druk die doel van die tug in die kerk as 'n geloofsgemeenskap op grond van geloofsoortuiging so uit: '... dat zij zich hebben te laten gezeggen door de wil van hun enige en volstrekte Heer, Jezus Christus ...'. Die oorhoofse bybelse koers vir leer en lewe is 'n saak van belydenis: die belydenis soos vervat in die antwoord op die Heidelbergse Kategismus vraag 2. Op vraag 1 se wat is jou 'enigste troos in lewe en in sterwe?' antwoord hierdie troosboek: dat ek met liggaam en siel in lewe en in sterwe nie aan myself nie, maar my getroue Verlosser Jesus Christus behoort. Dit is 'n saak wat God-Drieënig werk en daarom staan dit baie vas. Verder vra vraag 2: Hoeveel dinge moet jy weet om in hierdie troos salig te lewe en sterwe? Die antwoord bely die kern van die geestelike lewe voor God: drie dinge, naamlik die bybelse implikasies van sonde, verlossing en dankbaarheid (NG Kerk-Uitgewers 1982:39).

Woord- en belydenisgebonde tug gaan dus oor hartsgebondenheid aan drie dinge: die bybelse leer van sonde, verlossing en dankbaarheid. Dit gaan oor God se genade, naamlik dat ek as 'n sondaar tot die dood toe verlos en van sonde bevry word om met 'n nuwe lewe aan God gehoorsaam te lewe - gehoorsaam te lewe op al die kerklike en nie-kerklike akkers van God se koninkryk op aarde: die lewe waarvoor $\mathrm{Hy}$ ons uit genade bestem het (Ef 1:3-15). Die kerklike tug is 'n aspek van die sleutelmag wat die Here

7.Van der Linde (1983:231) praat van die kerklike tug wat teregwys, vermaan en bestraf om te oorreed tot bekering. In sy betoog dat die geestelike karakter van kerklike tug die heerskappy van die Woord impliseer, sê Nauta (1971):

Alleen bij wijze van overtuigen moet er te werk worden gegaan. Degenen die vermanen en tucht oefenen, moeten trachten met hun woord de consciëntie te benaderen, in de verwachting dat het hart van de aangesprokene zich zal ontsluiten ... dat hij tot bekering komt en breekt met de gevolge gedragslijn ... (p. 358).

Kleynhans (1988:163) wys daarop dat die kerklike tug handel oor enkelinge wat persoonlik aangekla en ondersoek word en nie oor'n groep persone gelyk nie.

8.Die vasstaande kennis en vertroue van Heidelbergse Kategismus antwoord 21 da God my uit genade en op grond van die verdienste van Christus vergewing van sondes, ewige geregtigheid en saligheid geskenk het (NG Kerk-Uitgewers 1982:44). 
aan sy kerk gegee het. Dit is die sleutelmag van Matteus 18:18 om die hemel oop en toe te sluit. Kerklike tug is dus soos die kerk: 'n doodernstige saak (NG Kerk-Uitgewers 1982:62-63; Sizoo sa:256).

Teen hierdie agtergrond kan dit verstaan word dat gereformeerde kerke, waaronder die NGK, nie meer soos by Dordt van die 'Christelijke straf' praat nie, maar van kerklike tug. In 'n verchristelikte samelewing hou die kerk alleen nie alles wat Christelik is in voorraad nie, maar vorm dit 'n instelling wat rondom die uit- en opbou van die Christelike geloof sy roeping as 'n geloofskring in die samelewing en as deel van God se koninkryk uitlewe.

Kerklike tug wil nie geestelik vervreem nie, maar innerlik buig en teuel, geestelike gemeenskap vestig en toerus vir 'n verlosde, bevryde lewe. Kerklike tugmaatreëls is ingestel op besinning, berou, omkeer en herstel (Spoelstra 1989:386; Strauss 2018b). As die Christelike tug in die konteks van DKO-1619 artikel 71 tot 81 met sy klem op die versoening van die getugtigde(s) met die gemeente en die gelowiges (DKO-1619 artikel 71,75, 78 in Pont 1981:184-185) werk, is dit nie straf wat wil wegstoot nie, maar wil versoen. Dit gaan oor berou en herstel om te versoen. DKO-1619 artikel 78 en versoening mik op die heropname van die een wat uitgeban is en deur 'boetvaardigheid' en 'n 'professie zijner bekering' herstel word in die gemeente. Hierdie opname kry die amptelike stempel van die gemeente deur die voorhou van die betrokke formulier aan die gemeente en die bekeerling, en die antwoord van laasgenoemde. Op pad na die ban word sondaar(s) blootgestel aan vermaning, 'bestraffen', 'vriendelijk vermanen' en sensuur. Dit is aksies wat vriendelik onderneem word sodat straf en vermaning by 'n omgee vir die oortreder, en sy berou en bekering pas. Immers, vriendelikheid en omgee wat dit nodig ag om te bestraf, is twee kante van dieselfde munt. Dit gaan hier om te bestraf of vermaan juis omdat diegene wat vermaan, omgee.

NGKO-1962 se vaderlike opsieners wat met liefde belangstel en uitreik na persone wat by 'n kerklike tugproses betrek word, gee 'n beeld wat DKO-1619 se versoening goed illustreer. ' 'n Tugvergadering wat nie as onpersoonlike, saaklike regters optree nie, maar as 'vaderlike opsieners met diepe ootmoed voor God', is reeds in die pylvak van pastoraal reverdige optrede teenoor die aangeklaagde(s) of, op grond van 'n gerug en na 1998, 'n verslag, die geïmpliseerde(s) (NGKO-1998:21). So 'n ingesteldheid stimuleer die gemeenskap van die gelowiges in die tugliggaam saam met hulle wat ondersoek word. Hierdie atmosfeer kanselleer die ongure verwysing na 'n kerklike tugsaak as 'n 'verhoor'. 'n Verhoor met 'partye' wat werk om hulle eie saak te wen en nie die kerkordelike oogmerke van die kerklike tug te bereik

9.Hierdie bruikbare beeld kom uit die Algemene Reglement van die Nederlands Hervormde Kerk van 1816 wat ongeveer 200 jaar na Dordt afwyk van die Hervormde Kerk van 1816 wat ongeveer 200 jaar na Dordt afwyk van die Nederlands-gereformeerde pad met ' $n$ kollegialisme ten opsigte van die kerk as ' $n$ sogenaamde vrywillige vereniging van gelowiges met kerkvergaderings wat van die kerkraad as die laagste tot die sinode as die hoogste strek. Artikel 16 van hierdie reglement verwoord dit prontuit: 'Het hoogste Kerklijk bestuur is opgedragen aan de Synode'. Vergelyk Sadler (1979:8) oor die opsieners en Pont (1991:31) wat die teks van hierdie reglement onveranderd publiseer. nie. Verhoor is 'n term wat vanweë die kerklike trant van die bepalings nie in DKO-1619, NGKO-1962 of GKNKO-1959 voorkom nie (Sadler 1979:120-124).

Ter wille daarvan dat regverdigheid en liefde bybelsgesproke geïntegreer is, moet kerklike tugliggame binne hulle vermoë seker maak van die aard en juistheid van die oortreding voordat daar tot tugmaatreëls wat in die situasie pas, oorgegaan word. Tugmaatreëls moet uit 'n vasstelling van die feite van die saak spruit - 'n deeglike ondersoek na die waarheid getuig van liefde en omgee - in 'n ondersoek deur die betrokke liggaam. Dit is 'n liggaam wat hom by die reëls vir natuurlike geregtigheid hou; 'n liggaam wie se bevinding soos in regs- of strafregtelike terme nie bo alle twyfel hoef te wees nie, maar, gemeet aan die getuienis voor die vergadering, 'meer waarskynlik is as nie'. Sadler (1979:50-51) toon dat die optrede van 'n kerklike tugliggaam regtens as kwasi-judisieel beskou word met alles wat dit meebring, onder meer die gebruik van die reëls van natuurlike geregtigheid - 'n geregtigheid wat ook Bybels verantwoord is ${ }^{10}$ (vgl. Du Plooy 2007:18-20; Kleynhans 1988:174-178; Van Dellen \& Monsma 1967:305).

\section{Gesag van kerklike tugvergaderings}

Die gesag waarmee 'n kerkvergadering 'n tugsaak aanpak, is die gesag waarmee alle kerkvergaderings hulle agendas moet benader: volgens NGKO-1962, 'n kerklike gesag deur Christus aan hulle verleen (NGK 1964:5; Strauss 2010:29-31).

Twee opmerkings kan hierby gemaak word: Eerstens kom die stelling in NGKO-1962 artikel 20a byna woord vir woord (uit Nederlands in Afrikaans) uit GKNKO-1959 artikel 28.1. NGKO-1962 artikel 20a bepaal dat elke kerkvergadering van NGKO-1962 artikel 18, te wete die kerkraad, ring, sinode en Algemene Sinode, 'na sy eie aard, 'n kerklike gesag deur Christus aan hulle verleen' het (nie besit of oorneem nie). Anders gesê: vir die uitvoering van sy agenda of opdrag het elke kerkvergadering gesag wat Christus aan hom verleen of uitleen. Dit is 'n gesag waarvan Christus nie die besit prysgee nie, maar waarmee hy die vergadering deur die Heilige Gees toerus of vir sy taak vervul (Hand 2:4; Ef 5:18; vgl. Jansen 1952:166; Strauss sa:16-20). Dit is Christus wat met gesag uitstuur en die kerkvergadering toerus om sy gesag deur Christus verleen, reg te gebruik. Die opdrag kom van Jesus Christus en omdat gesag van Christus Woordgesag is, moet die taak aan Hom verantwoordelik en Woordgetrou uitgevoer word. Christus moet in alles gehoorsaam en geëer word. Ongehoorsaamheid aan Christus bedroef die Heilige Gees as die Gees van Christus (Rom 8:9; Ef 5:30; Strauss sa:37-40). Dit gaan hier om gesag en toerusting vir 'n omlynde opdrag. Gesag is deel van die toerusting van die gelowiges omdat dit deel uitmaak van die totale verlossingspakket van God in Christus deur die Heilige Gees. Gesag deur Christus verleen, stimuleer gehoorsaamheid. Sonder hierdie gesag, vervaag die opdrag.

10.Vir die regskante van die Johannesevangelie, kyk Johannes 3:31-36, 5:30-47, 7:25-27, 18:19-24. Die begrippe getuig en getuienis in Johannes dra 'n regskarakter teen die agtergrond van 'n Joodse hofsaak. 
DKO-1619 bevat weinig kommentaar oor kerklike gesag en die gesag van kerklike tugvergaderings. Daarom verruim die twintigste-eeuse verwoording van kerklike gesag in GKN-1959 en NGKO-1962 die hantering van die kerklike tug: bewoording van GKNKO-1959 wat NGKO-1962 net so oorneem. Dit is die verwoording van 'n geestelike feit wat die hantering van die kerklike tug beskerm teen ongemotiveerdheid en desperaatheid by kerklike tugliggame. Kerklike tugliggame funksioneer op gesag van God in Christus. Hierdie afleiding spruit uit sistematiese oorwegings by die uitleg van 'n kerkorde: om die bepaalde artikel binne die geestelike of geloofstradisie van die betrokke kerk te lees (Du Toit 1991:49-51; Van de Beek 1992:64).

NGKO-1962 artikel 20a word gevolg deur NGKO-1962 artikel 20b - 'n artikel wat by GKNKO-1959 artikel 28.2 aansluit en bepaal dat elke vergadering 'n eie aard en taak het wat in kerkverband gekoester moet word: die gesag van die ring oor die kerkraad is dieselfde as die gesag van die sinode oor die ring en die Algemene Sinode oor die sinode. Sonder om dit uitvoerig te omskryf, volg NGKO-1962 artikel 20b hiermee die gereformeerde stelreël in DKO-1619 artikel 36 wat waak teen 'n devaluering van elkeen van hierdie vergaderings (Nauta 1971:121; NGK 1964:5; Pont 1981:180). Hiermee gee GKNKO-1959 en NGKO-1962 ook 'n dieper dimensie aan die verstaan van die gesag van kerkvergaderings.

\section{Geestelike aard van kerklike tugvergaderings}

In die lig van dit wat reeds gesê is, wek die stelling dat kerklike tug geestelik van aard is, nie verbasing nie. Calvyn beklemtoon dit al. Die kerklike tug 'hangt voor het grootste deel aan de sleutelmacht (daar is na hierdie sleutelmag verwys) en de geestelijke rechtspraak'. Die hervormer van Genevé bestempel die kerklike tug as die senuwees van die kerk wat lidmate by mekaar hou. Daarsonder verloor die kerk die koers van die Woord en verdwaal hy op paaie van verstrooiing en agteruitgang (Sizoo sa:257).

Getrou aan sy bondige, praktykgerigte aard, brei DKO-1619 nie uit op sy aanduiding van die kerklike of, soos hy dit noem, Christelike tug as 'geestelijk' nie. Wat wel die belangrikheid daarvan vir DKO-1619 onderstreep, is dat sy prosedure vir die tug in die res van artikel 71 tot 81 (Pont 1981:184-185) die geestelike karakter daarvan veronderstel. In sy heel eerste sin oor die kerklike tug sê DKO-1619 in artikel 71 wel dat hierdie tug 'geestelijk' van aard is. Vir DKO1619 staan die besef van die geestelike karakter van die kerklike tug dus bo-aan geskryf. Volgens dieselfde artikel 71 is hierdie tug - hy sê dit nie in soveel woorde nie godsdienstig eties van aard: om die sondaar met die kerk as die liggaam van Christus te versoen en ergerlike dinge onder die gelowiges te verwyder (Pont 1981:184). Die woorde verzoenen of verzoening kom drie keer in die 11 artikels voor. Dit is versoening wat volg op 'kerklijke censuren' oor 'n 'openbare ergernis of sonde' of 'n 'openbare grove zonde' (artikel 71, 72, 74, 76, 79). Kerklike tug word toegepas deur 'vriendelijke' vermanings (artikel 74, 76, 77, 81). Indien geen boetvaardigheid of berou volg nie en die vermanings nie suksesvol is nie (artikel 73, 76, 78), volg daar sensuur of 'n weerhouding van die sakramente (artikel 76). As hierdie maatreël in die oё van die tugliggaam misluk, volg die afsnyding (artikel 77, 78). DKO-1619 is nie ingestel op beuselagtighede nie, maar 'grove zonden'. DKO-1619 soek na versoening van die sondaar(s) met die gemeente van Christus en sy of haar naaste deurdat almal uit die versoening met Christus as Hoof van die kerk leef. Die terme hier genoem, vorm die (struktuur-)draers van die betekenis van DKO-1619 se bepalings oor die kerklike tug.

In sy kommentaar op DKO-1619 se geestelike aard van die kerklike tug, wys Jansen daarop dat DKO-1619 hierdie uitdrukking verbind aan die bepaling dat die 'Christelike' tug niemand vrystel van die 'burgerlijk gericht of straf' van die owerheid nie, omdat hy die owerheid wil gerusstel: die destyds invloedryke gereformeerde kerk in Nederland wou nie sy grense oorskry deur kerklike optrede op die terrein van die staat nie. Boonop moet DKO-1619 amptelik goedgekeur word deur die owerheid om daaraan die 'karakter' van 'n landswet en meer gesag te gee. Wat Jansen betref, dra die kerklike tug 'n geestelike karakter wat rus op die geestelike mag wat die Here aan sy kerk gee. Dit is 'n mag wat Hy op gedeeltes soos Efesiërs 4:11, Handelinge 20:28 en 1 Korintiërs 12:28 grond. Daarom werk die tug met geestelike wapens soos vermaning, waarskuwing, oortuiging, sensuur en die ban (Jansen 1952:303). In moderne terme sal geestelike tug medemenslik, moreel- en geloofsvormend wees (Strauss 2018a).

NGKO-1962 loop op dieselfde beginselspore oor die kerklike tug as DKO-1619. Die aanpak en inkleding daarvan verskil egter aansienlik. Daarby is NGKO-1962 uit meer bronne as DKO-1619 en GKNKO-1959 beïnvloed in sy bepalings oor die tug. Op NGKO-1962 se gebruik van die beeld dat kerkvergaderings die tug soos liefdevolle vaderlike opsieners moet hanteer, is reeds gewys.

Nadat hy oor die oogmerke van die tug as tot eer van God, die heil van die kerk en behoud van die sondaar bestempel het, open NGKO-1962 sy rekening oor die kerklike tug - soos DKO-1619 - met die oortuiging dat dit 'n geestelike karakter dra. Nog meer as DKO-1619 artikel 71 se saaklike hantering van die saak, verwoord NGKO-1962 artikel 56 se 'openbare ergerlike sondes', 'vaderlike opsieners', 'diepe ootmoed', 'tere liefde', 'belangstelling' en 'hartgrondige berou' die geestelike karakter van die tug. Soos Jansen verbind NGKO1962 tugmaatreëls soos vermaning, sensuur en afsnyding aan die geestelike karakter van die tug.

\section{Sondelysie}

NGKO-1962 artikel 64 haak egter vas by die toepassing van DKO-1619 of 'n menslike maatreël in die verre verlede, historisme en afwyking van die idee van 'n speelruimte by tugvergaderings. By die bedienaars van die Woord voeg hy 'n lysie van die 'ergerlikste sondes': owerspel, moord, meineed en growwe diefstal. In sulke gevalle mag daar 
'behalwe by hoë uitsondering' geen herstel in die amp by 'n afgesette leraar -' $n$ taak van die Algemene Sinode - plaasvind nie. NGKO-1962 skep so, op grond van sy tydsgebonde ervaring in 1962, 'n staande lys van die ergerlikste sondes los van die konteks waarin dit voorkom [outeur se kursivering]. Daarteenoor kies hy ook téén die onafhanklike vastelling van 'n 'openbare ergerlike sonde' in konteks deur ' $n$ - dit is die veronderstelling - mondige NGK-tugliggaam. Ten opsigte van die dominees ignoreer NGKO-1962 hiermee die pastorale speelruimte by tugliggame waarvoor kundiges pleit (NGKO 1964:14). Daarby systap NGKO-1962 vir GKNKO-1959 wat nie so 'n lysie van ergerlike sondes met hulle gevolge het nie en sluit hy hom aan by DKO-1619 artikel 80 (Pont 1981:185). ${ }^{11}$ Moontlik is die verlede teenoor die hede deur die Algemene Sinode van 1962 as 'n beter maatstaf beskou.

Met sy verwysing na 'weg ... nemen' van die 'grove zonde', 'boetvaardigheid' en 'ontheffing' is DKO-1619 ingestel op berou en herstel as die oogmerke van die kerklike tug: bo alles die eer van God, maar ook die heil van die gemeente en die berou en behoud van die sondaar. Getrou aan die gereformeerde kerke van sy tyd, sluip die sondelysie van DKO-1619 artikel 80 egter ook in. NGKO-1962 se vaderlike liefde en belangstelling gee 'n ekstra dimensie aan die opheffing van tug. Hy wy sy hele artikel 64 met vier hoofpunte daaraan. Ruimtegewys is NGKO-1962 artikel 64 langer as enige ander artikel oor die kerklike tug (NGKO 1964:14).

Sonder om dit uitvoerig te motiveer, moet dit in hierdie stadium duidelik wees dat 'n tugwaardige of openbare ergerlike sonde op die agenda van 'n NG Kerkvergadering ten diepste bots met die Woord van God, en openbare aanstoot - om Christus ontwil - gee. 'n Tugwaardige sonde bots met die Bybel wat die norm van alle norme, die sola scriptura, in die NGK as 'n gereformeerde kerk is. Daarby aanvaar 'n gereformeerde kerk dat die waarhede in sy belydenisskrifte kernwaarhede van die Bybel is en dat 'n verwerping daarvan in konteks 'n openbare ergerlike sonde of tugwaardig kan wees. Die verbetering (reformasie) van kerklike belydenisskrifte is ' $n$ ander saak. Behalwe dat 'n oortreding in konteks voor 'n vergadering van die NGK van 'n openbare ergerlike aard moet wees, moet dit die Bybel en die belydenis weerspreek. Dit gaan nie hier om sekere Skrifgedeeltes of -tekste nie, maar om die konstantes van Woord en belydenis in 'n eietydse konteks (Strauss 2018c). 'n Vergelykbare figuur in die kerkregering lê natuurlik in 'n kerkorde met konstantes, aangepas by die eise van die dag.

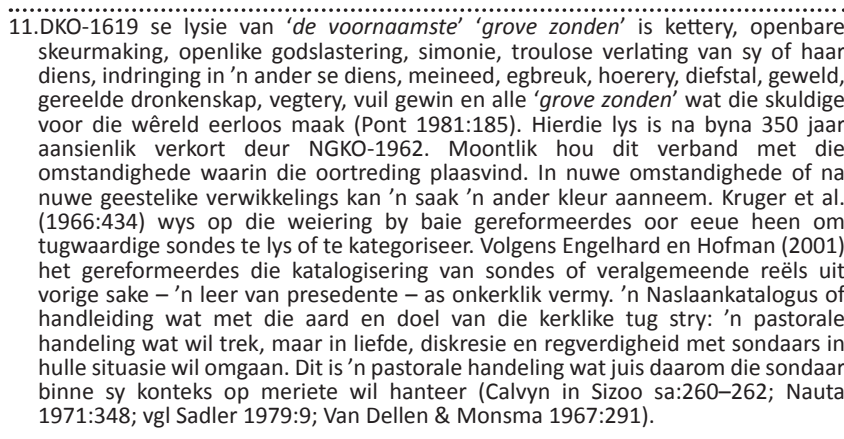
skeurmaking, openlike godslastering, simonie, troulose verlating van sy of haa diens, indringing in ' $n$ ander se diens, meineed, egbreuk, hoerery, diefstal, geweld, gereelde dronkenskap, vegtery, vuil gewin en alle 'grove zonden' wat die skuldige voor die wêreld eerloos maak (Pont 1981:185). Hierdie lys is na byna 350 jaa aansienlik verkort deur NGKO-1962. Moontlik hou dit verband met die omstandighede waarin die oortreding plaasvind. In nuwe omstandighede of na nuwe geestelike verwikkelings kan ' $n$ saak ' $n$ ander kleur aanneem. Kruger et al. (1966:434) wys op die weiering by baie gereformeerdes oor eeue heen om tugwaardige sondes te lys of te kategoriseer. Volgens Engelhard en Hofman (2001) tugwaardige sondes te lys of te kategoriseer. Volgens Engelhard en Hofman (2001) het gereformeerdes die katalogisering van sondes of veralgemeende reëls uit vorige sake -'n leer van presedente - as onkerklik vermy. ' $n$ Naslaankatalogus of handleiding wat met die aard en doel van die kerklike tug stry: ' $n$ pastoral handeling wat wil trek, maar in liefde, diskresie en regverdigheid met sondaars in hulle situasie wil omgaan. Dit is 'n pastorale handeling wat juis daarom die sondaar binne sy konteks op meriete wil hanteer (Calvyn in Sizoo sa:260-262; Nauta 1971:348; vgl Sadler 1979:9; Van Dellen \& Monsma 1967:291).

Openbare ergerlike sondes as tugwaardige sondes is sondes wat in hulle situasie deur die toepaslike kerkvergadering vir die omvang van hulle openbare rugbaarheid, hulle aanstootlikheid of ergerlikheid en, ten diepste, hulle onskriftuurlikheid of ontkenning van die belydenisskrifte geweeg is. Die Bybel as norma normans en sy belydenis as norma normata 'diep' onder die Bybel (Bavinck 1967:401-402), is die lewenskompasse van 'n gereformeerde kerk.

Met hierdie punte sluit NGKO-1962 ook by DKO-1619 aan.

\section{Slot}

Op NGKO-1962 met sy kerklike tug wat op'n geestelike manier deur vermaning, sensuur en afsnyding wil lei tot berou en herstel, is gewys. DKO-1619 se doel met die kerklike tug as versoening met God en die gemeente word gehandhaaf, dog deur NGKO-1962 verwoord as tug tot eer van God, heil van die gemeente en behoud van die sondaar. Dordt se vriendelike vermanings word in NGKO-1962 verdiep as die tug van vaderlike opsieners, diepbewoë vanweë hulle eie redding uit genade, in 'tere' liefde (die piëtistiese trek in die NGK van 1962?). Dit is vaders wat regverdig optree in 'n tugsaak en daarom aan NGKO-1962 artikel 58 se voorskrif van 'n grondige ondersoek ter wille van die waarheid voldoen. Hierdie ondersoek gee ook aan die aangeklaagde of die een wat in 'n gerug geïmpliseer word, 'genoegsame geleentheid' om sy of haar kant van die saak te stel en hom- of haarself te verdedig. Maar juis omdat dit gaan oor DKO-1619 se versoening met God en die gemeente, en omdat die Bybel nie alles oor alles nie, maar iets oor alles in die lewe sê, gaan die tug in NGKO-1962 'oor die hele lewenswandel van lidmate'. Hierdie bepaling is ' $n$ wins. Die Bybel gee immers die lens van die geloof in God en alles wat daarmee verband hou, aan die kerk as sy betroubare bril vir die lewe. Dié wins word verhoog deur die begrip hele lewenswandel.

Met sy verwysing na die 'weg ... nemen' van die 'grove zonde', 'boetvaardigheid' en 'ontheffing' is DKO-1619 ingestel op berou en herstel as die oogmerke van die kerklike tug. Getrou aan die kerk van sy tyd, sluip die sondelysie as 'n verskynsel in DKO-artikel 80 egter by NGKO-1962 artikel 64 in. NGKO1962 se vaderlike liefde en belangstelling gee 'n ekstra dimensie aan die opheffing van die tug. Daarom wy hy sy hele artikel 64 met vier hoofpunte uitvoerig daaraan. Ruimtegewys is NGKO-1962 artikel 64 langer as enige een van die ander artikels oor die kerklike tug: artikel 56 tot 64 . Daarmee vorm die opheffing van die tug die regte noot om hierdie deel van NGKO-1962 mee af te sluit.

\section{Erkenning}

\section{Mededingende belange}

Die outeur verklaar dat daar geen finansiële of persoonlike verbintenis is met enige party wat hom nadelig kon beïnvloed in die skryf van hierdie artikel nie.

\section{Outersbydrae}

P.J.S. was die enigste outeur betrokke by die skryf van die artikel. 


\section{Etiese oorweging}

Hierdie artikel volg alle etiese standaarde vir navorsing.

\section{Befondsing}

Hierdie navorsing het geen spesifieke toekenning ontvang van enige befondsingsagentskap in die openbare, kommersiële of nie-winsgewende sektore.

\section{Data beskikbaarheidsverklaring}

Die deel van data is nie van toepassing op hierdie artikel nie, aangesien geen nuwe data in hierdie studie geskep of ontleed is nie.

\section{Vrywaring}

Die sienings en menings wat in hierdie artikel uitgedruk word, is dié van die outeur en weerspieël nie noodwendig die amptelike beleid of posisie van enige geaffilieerde agentskap van die outeurs nie.

\section{Literatuurverwysings}

Bavinck, H., 1967, Gereformeerde Dogmatiek IV, (5de onveranderde druk), Kok, Kampen.

Biesterveld, P. \& Kuyper, H.H., 1905, Kerkelijk handboekje, Kok, Kampen.

Bouwman, H., 1985, Gereformeerd Kerkrecht II, (3de onveranderde druk), De Groot Goudriaan, Kampen.

Celliers, A., 2003, Skrif en kerkorde, D.Th-proefskrif, Universiteit van die Vrystaat, Bloemfontein

Du Plooy, A.I.R., 2007, 'Beginsels vir regspraak in die kerk', Die Kerkblad, April, pp. 18-20.

Du Toit, P.R., 1991, 'Die uitleg van 'n kerkorde', in P.J. Strauss (red.), Byderwets en Gereformeerd, pp. 46-64, Pro Christo, Bloemfontein.

Engelhard, D.H. \& Hofman, L.J., 2001, Manual of Christian Reformed Church government, CRC Publications, Grand Rapids, MA.

Gray, J.S. \& Tucker, J.C., 1999, Presbyterian Polity, Louisvale, Geneva.

Jansen, J., 1952, Kerkorde der Gereformeerde Kerken, Kok, Kampen.

Jonker, W.D., 1959, En as jou broeder sondig, NG Kerk-Uitgewers, Kaapstad.

Jonker, W.D., 1965, Om die regering van Christus in sy kerk, Universiteit van Suid-Afrika (UNISA), Pretoria.
Kleynhans, E.P.J., 1988, Gereformeerde Kerkreg IV, NG Boekhandel Transvaal, Pretoria. Koffeman, L.J., 2009, Het goed recht van de kerk, Kok, Kampen.

Kruger, L.S., Du Plessis, H.L.M., Spoelstra, B. \& Spoelstra, T.T., 1966, Handleiding by die kerkorde, Pro Rege, Potchefstroom.

Langner, D., 2007, Teen die hele wêreld vry - Koot Vorster, segsman of profeet, Griffel, Pretoria.

Nauta, D., 1971, Verklaring van de Kerkorde van de Gereformeerde Kerken in Nederland, Kok, Kampen.

NGK, 1957, Handelinge Raad van die Kerke, sn, sl.

NGK, 1962, Handelinge van die Algemene Sinode, sn, sl.

NGK, 1964, Kerkorde, NG Kerk-Uitgewers, Kaapstad/Pretoria.

NGKO-1998, 1998, Die Kerkorde 1998, Hugenote, Wellington.

NG Kerk-Uitgewers, 1982, Ons glo ... Die Drie Formuliere van Eenheid en die ekumeniese belydenisse, NG Kerk-Uitgewers, Kaapstad.

Plomp, J., 1992, 'Kerk en recht', in W. van 't Spijker \& L.C. van Drimmelen (eds.), Inleiding tot de studie van het kerkrecht, pp. 32-42, Kok, Kampen.

Pont, A.D., 1981, Die historiese agtergronde van ons kerklike reg I, HAUM, Pretoria.

Pont, A.D., 1991, Die historiese agtergronde van ons kerklike reg II, Kital, Pretoria.

Rossouw, P., 1979, Kerkvergaderings, NG Kerkboekhandel, Pretoria.

Sadler, T.H.N., 1979, Die kerklike tughandeling, NG Kerkboekhandel, Pretoria.

Sizoo, A., sa, Johannes Calvijn Institutie, Meinema, Delft.

Smit, D.J., 2009, Essays on being reformed, Sun Media, Stellenbosch.

Spoelstra, B., 1989, Gereformeerde kerkreg en kerkregering, Teologiese Skool, Hammanskraal.

Strauss, P.J., 2009, 'Kerkreg 'n dienende reg?', Ned Geref Teologiese Tydskrif (NGTT) 50(3 en 4), 492-499.

Strauss, P.J., 2010, Kerk en orde vandag, Sunmedia, Bloemfontein.

Strauss, P.J., 2018a, 'Die Kerkorde van die Ned Geref Kerk 2013: Kanaal of hindernis vir kerklike tug?', Verbum et Ecclesia 39(1), a1747. https://doi.org/10.4102/ve. v39i1.1747

Strauss, P.J., 2018b, 'Kerklike tug: Pastoraal-kerkregtelik van aard en daarom billik en regverdig? NG Kerkorde artikel 60.3 'n geesteskind van die Dordtse Kerkorde?', In die Skriflig, a2336. https://doi.org/10.4102/ids.v52i2.2336

Strauss, P.J., 2018c, 'Tugwaardige sondes in drie gereformeerde kerkordes', In die Skriflig, a2388. https://doi.org/10.4102/ids.v52i1.2388

Strauss, P.J., s.a., Die Gees werk soos Hy wil ..., VCHO, Bloemfontein.

Van de Beek, A., 1992, 'Hermeneutiek van het kerkrecht', in W. Van 't Spijker \& L.C. Van Dimmelen (eds.), Inleiding tot de studie van het kerkrecht, pp. 59-72, Kok, Kampen (tweede druk).

Van Dellen, I. \& Monsma, M., 1967, The revised church order commentary, Zondervan, Grand Rapids.

Van der Linde, G.P.L., 1983, Die Kerkorde, PTP, Potchefstroom.

Van der Watt, P.B., 1973, Die Loedoffsaak en die NG Kerk 1862-1962, Tafelberg, Kaapstad.

Visser, J., 1999, Die Kerkorde in praktyk, EFJS, Orkney.

Vorster, J.D., 1960, 'Die kerkorde van die Ned Geref Kerke: Besware daarteen en betekenis daarvan', Nederduitse Gereformeerde Teologiese Tydskrif (NGTT), September, $12-18$ 